\title{
Assessment of concentrations of interleukin-25 in bronchial asthma - preliminary studies
}

\section{Ocena stężeń interleukiny 25 w przebiegu astmy oskrzelowej- badania wstępne}

\author{
Małgorzata A. Czarny-Działak¹, Anna Słuszniak² \\ ${ }^{1}$ Department of Family Medicine and Geriatrics, Institute of Medical Sciences, Faculty of Medicine and Health Science, \\ Jan Kochanowski University, Kielce, Poland \\ Head of the Department: Andrzej Jaroszyński MD, PhD, Prof. JKU \\ ${ }^{2}$ Tumor Marker Facility, Świętokrzyskie Oncology Centre, Kielce, Poland \\ Head of the Department: Prof. Stanisław Głuszek MD, PhD
}

Key words: cytokines, asthma, interleukin-25.

Słowa kluczowe: cytokiny, astma, interleukina 25.

\begin{abstract}
Introduction: Studies have demonstrated an important role of cytokines in the development of asthma, in particular the balance between them disturbed in favour of pro-inflammatory cytokines. Interleukin-25 (IL-25) belongs to the family of cytokines from IL-17. Its role in the pathogenesis of allergic diseases of the respiratory tract is not entirely clear. The study took into account the fact that the role can be very important due to the dual mechanism of action as an anti-inflammatory and inflammatory stimulant.

Aim of the research: To assess whether the concentration of IL-25 depends on the the severity of the course of asthma.

Material and methods: The study involved 80 people: 20 volunteers and 60 patients with asthma - 20 people with mild persistent asthma, 20 with moderate, and with 20 severe. All patients were maintained on a course of asthma control. From each patient, blood was drawn to assess IL-25 ELISA test; all patients also had spirometry performed (in the framework of visits to the clinic).

Results: In none of the cases of the people from the examined group there was an increased level of IL-25. However, some subjects (17) had higher levels of this interleukin than other people - among these were four volunteers and 13 patients with asthma.

Conclusions: In the future patients should be checked during exacerbations of asthma and have the response time tried to be extended to maximum so that we can measure lower concentrations, which within a standard procedure could has not been varied (found below the lowest standard).
\end{abstract}

\section{Streszczenie}

Wprowadzenie: Dzięki immunologii znacznie więcej wiadomo na temat patogenezy astmy oskrzelowej. Wyniki badań wykazały znaczącą rolę cytokin w rozwoju astmy, zwłaszcza zaburzonej równowagi między nimi na korzyść cytokin prozapalnych. Interleukina 25 (IL-25) należy do rodziny cytokin z grupy IL-17. Jej znaczenie w patogenezie chorób alergicznych dróg oddechowych nie jest do końca poznane. W badaniu brano pod uwagę, że jej rola może okazać się bardzo istotna ze względu na podwójny mechanizm działania - zarówno przeciwzapalny, jak i pobudzający zapalenie.

Cel pracy: Zbadanie, czy stężenie IL-25 w przebiegu astmy oskrzelowej zależy od stopnia jej ciężkości.

Materiał i metody: W badaniu wzięło udział 80 osób: 20 ochotników oraz 60 pacjentów z astmą, w tym 20 osób z astmą przewlekłą łagodną, 20 z umiarkowaną oraz 20 z ciężką. U wszystkich chorych choroba była pod kontrolą. Od każdego chorego pobrano krew do oznaczenia IL-25 testem Elisa, u wszyskich chorych dodatkowo wykonano spirometrię (w ramach wizyt w poradni).

Wyniki: U żadnej osoby z badanej grupy nie stwierdzono podwyższonego poziomu IL-25. U części (tj. 17) stwierdzono jej większe stężenie niż u pozostałych osób - wśród nich było 4 ochotników, natomiast 13 chorych z astmą. Być może brak podwyższonego stężenia IL-25 w surowicy u wszystkich chorych wynika z faktu, że były to osoby z astmą kontrolowaną. Wnioski: W przyszłości należałoby sprawdzić chorych w trakcie zaostrzenia astmy oraz spróbować wydłużyć czas reakcji do maksimum, co umożliwi pomiar mniejszych stężeń, które przy standardowym postępowaniu nie zostały zróżnicowane (znalazły się poniżej najniższego standardu). 


\section{Introduction}

Asthma is a chronic inflammatory disease of the airways, which affects between $1 \%$ and $18 \%$ of people depending on the country (there are countries where prevalence is high, such as England or New Zealand, and those in which it is low, such as Albania and Greece) [1]. Most therapeutic problems are related to the so-called "difficult to treat asthma" - it is now believed that up to $10 \%$ of patients with asthma do not respond to standard treatment [2]. It is these patients who are saddled with the highest risk of death, and it is for them that there is a need to concentrate on trials of innovative diagnostic and treatment [3]. Allergic asthma is a chronic respiratory disease, which is inflammatory, and in which many cells and released by the substance - in this process a major role is played by cytokines from Th2 cells [1]. A major role is also played in inflammation in asthma by mast cells, released mediators of which cause bronchospasm and eosinophils, also via the release of eosinophil major basic protein (EMBP), which damages the lining of the airways [2]. the diagnostic process should therefore be concentrated on the treatment of these cells and of the released by substances. Individual cytokines have a very diverse role in the development or suppression of allergic inflammation. Cytokines are molecules of a glycoprotein, and they regulate many vital functions of cells. They are involved in inflammatory reactions and in the regulation of immune and haematopoietic processes [4-7]. Frequently they have a pleiotropic mechanism of action (the ability to act on various cells and induce various effects) and redundancy (when different cytokines produce the same effect). They may also act in relation to each other synergistically or antagonistically and induce a cascade feedback, positive and negative. Cytokines exert their action only by the presence of specific target cells for these receptors. They usually carry information between cells in very small distances [5].

Interleukin (IL)-25 belongs to the IL-17 cytokine family, which also shows pleiotropic properties; its receptor is IL-17RB receptor [8]. Its former name was IL-17E. To the IL-17 family, besides IL-17E, also belong: IL-176, IL17-C, IL-170, and IL-17F - each of them is characterised by certain differences in action [5]. Interleukin 25 is excreted by helper lymphocytes Th2 and mast cells, it inhibits production of IL-1 and IL-23 $[9,10]$, whereas it induces production of other cytokines, such as IL-4, IL-5, IL-13, and eotaxin in different tissues, mainly by Th2 lymphocytes, acting in an autocrine and paracrine way [11]. It stimulates eosinophils and production of IgE antibodies related to development of allergy. It is stated that IL-25 improves regulatory surface of adhesion molecule - ICAM-1 and inhibits the other molecule - ICAM-3 provides selection of eosinophils depending on the amount of the interleukin - IL-25. Due to this, IL-25 facilitates the leukocyte extravasation (diapedesis) processes of neutrophils, which are important factors in the development of the severe form of asthma. It has been proven that after applying antibody directed against the adhesion molecule (ICAM-1), the inflow of neutrophils to the respiratory tract is lessened. Interleukin 25 also extends the lifespan of eosinophils, the major cells in the inflammatory process in asthma [12]. Interleukin takes part in chronic inflammation, especially in the gastrointestinal tract, and induces inflammation in the lungs and respiratory tracts [13]. It is known that it is the cytokine which controls type 2 immune response, and especially important is its role in controlling the initiation and the severity of Th2 response course that is done via other cytokines: IL-4, IL-5, and IL-13. As we know, the Th2 advantage over Th1 is characteristic for allergic diseases [13]. It has a dual mechanism of action. On the one hand, it is a cytokine that prevents debilitating inflammation - suppressing development of chronic inflammatory diseases; on the other hand, it boosts immune response, thus fostering development of inflammatory diseases such as asthma or other allergic diseases. The action of IL-25 is well known in the case of animal models, whereas its mechanism of action in the case of humans requires further research [12]. Knowledge of the mechanism of action of IL-25 may be relevant to a new therapeutic approach in the treatment of asthma.

\section{Aim of the research}

The aim of the study was to assess whether levels of IL-25 in bronchial asthma depend on the degree of its gravity.

\section{Material and methods}

The blood samples were taken (from ulnar veins) from a group of 80 respondents (20 volunteers and 60 patients suffering from asthma: 20 with chronic mild asthma, 20 with moderate, and 20 with severe) into tubes with gel - with no anticoagulant, which were left for $30 \mathrm{~min}$ at room temperature. Next, after the end of the coagulation process, the samples were swirled for $20 \mathrm{~min}$ at $2500 \mathrm{rpm}(1000 \times \mathrm{g})$. Then serum was separated into 3 tubes, and samples were stored at $-70^{\circ} \mathrm{C}$ until collection of the appropriate number of respondents. Concentration of interleukin was determined by enzyme-linked immunosorbent assay ELISA, with the use of reagent kit SEB $694 \mathrm{Hu}$. The actual measuring range of the kit varied from 15.6 to $1000 \mathrm{ng} / \mathrm{ml}$. After the initial dilution of the standard 10,000 pg/ml, standards $1000 \mathrm{pg} / \mathrm{ml}, 500 \mathrm{pg} / \mathrm{ml}$, $250 \mathrm{pg} / \mathrm{ml}, 125 \mathrm{pg} / \mathrm{ml}, 62.5 \mathrm{pg} / \mathrm{ml}, 31.2 \mathrm{pg} / \mathrm{ml}$, and $15.6 \mathrm{pg} / \mathrm{ml}$ were obtained. In the kit 96 -well plates coated with IL-25-specific antibodies conjugated with biotin were utilised. After adding standards and patients' serum, the well plates were incubated for $2 \mathrm{~h}$ at $37^{\circ} \mathrm{C}$. 
Table 1. Classification of asthma severity based on clinical symptoms by GINA 2007

\begin{tabular}{|c|c|c|c|}
\hline Clinical symptoms & Chronic mild asthma & Chronic moderate asthma & Chronic severe asthma \\
\hline Daily symptoms & $\begin{array}{l}\text { More than once a week, } \\
\text { less than once a day }\end{array}$ & Every day & Every day \\
\hline Night symptoms & $\begin{array}{l}\text { More often than twice } \\
\text { a month }\end{array}$ & More than once a week & Often \\
\hline Exacerbations & $\begin{array}{c}\text { They can interfere with } \\
\text { sleep and hinder daily } \\
\text { activity }\end{array}$ & $\begin{array}{c}\text { They can interfere with sleep and } \\
\text { hinder daily activity }\end{array}$ & Often \\
\hline $\mathrm{FEV}_{1}$ or PEF & $\geq 80 \%$ predicted & $60-80 \%$ predicted & $\leq 60 \%$ predicted \\
\hline Variability $\mathrm{FEV}_{1}$ or PEF & $<20-30 \%$ & $>30 \%$ & $>30 \%$ \\
\hline Other & - & $\begin{array}{l}\text { The necessity of short-acting inhalation } \\
\qquad \beta_{2} \text {-mimetic section }\end{array}$ & $\begin{array}{l}\text { Limitation of physical } \\
\text { activity }\end{array}$ \\
\hline
\end{tabular}

$F E V_{1}$ - forced expiratory volume in $1 \mathrm{~s}$, PEF- peak expiratory flow.

Table 2. The criteria for disease control according to GINA 2007

\begin{tabular}{|lcccccc|}
\hline Characteristics & Daytime symptoms & $\begin{array}{c}\text { Limitation } \\
\text { of activities }\end{array}$ & $\begin{array}{c}\text { Nocturnal } \\
\text { symptoms/ } \\
\text { awaking }\end{array}$ & $\begin{array}{c}\text { Need for reliever/ } \\
\text { rescue inhaler }\end{array}$ & $\begin{array}{c}\text { Lung } \\
\text { function }\end{array}$ & $\begin{array}{c}\text { Exacer- } \\
\text { bations }\end{array}$ \\
\hline Controlled & $\begin{array}{c}\text { None } \\
\text { (twice or less/week) }\end{array}$ & None & None & $\begin{array}{c}\text { None } \\
\text { (twice or less/week) }\end{array}$ & Normal & None \\
\hline
\end{tabular}

Hat the patient had asthma controlled, all the criteria would have had to be met. All patients were maintained during disease control.

Content was extracted and $100 \mu \mathrm{l}$ of reagent $\mathrm{A}$ added. Next, the well plates were incubated for $1 \mathrm{~h}$ at $37^{\circ} \mathrm{C}$. After triple rinsing of wells, $100 \mu$ l of reagent B was added and incubated for another $30 \mathrm{~min}$ at $37^{\circ} \mathrm{C}$. Content was extracted; the well plates rinsed five times. $90 \mu \mathrm{l}$ of substrate solution (TMB) was added and the well plates were incubated for $20 \mathrm{~min}$ at $37^{\circ} \mathrm{C}$ (protecting them from direct sunlight).

Next, $50 \mu$ l of sulphuric acid (stop solution) was added in order to complete the reaction.

The well plates were read at $450 \mathrm{~nm}$ on an ELISA reader with the possibility of automatic calculation of concentration. The concentration of IL-25 in samples was determined by comparing the optical density of the sample, compared to the standard curve. In 17 of 80 test samples, a colour reaction was observed; however, it was not as significant as differentiation between the blind test and the lowest calibration point on the calibration curve $(15.6 \mathrm{pg} / \mathrm{ml})$.

According to the observations, concentration of IL-25 in the group of patients were in the lower range of the calibration curve. In order to adjust the calibration curve to the tested group of patients, during subsequent set, a variant without $1000 \mathrm{pg} / \mathrm{ml}$ and $500 \mathrm{pg} / \mathrm{ml}$ standards should be considered (these calibration points are rejected by the reader as the optical density is located over the measurement capabilities of the reader) as well as expanding incubation time, after adding TMB, to $25 \mathrm{~min}$ (the producer gives an alloying time of reaction of 15-25 min). We will assume that the extension of reaction time to maximum will enable us to measure lower concentrations, which - in a standard procedure - were not differentiated (they were located below the lowest standard). In the study 80 people participated: 20 volunteers and 60 patients suffering from asthma: 20 with chronic mild asthma, 20 with moderate, and 20 with severe. The grouping criteria to a certain degree of severity were clinical signs, categorised according to the Global Initiative for Asthma (GINA) (Tables 1 and 2).

Among patients were 18 men and 42 women, patients' age ranged from 19 to 82 years. In the group of patients suffering from severe asthma, there were 7 men and 13 women; among patients with chronic moderate asthma there were 6 men and 14 women; and among patients with mild asthma there were also 6 men and 14 women. Affiliation to a given group was assessed by the degree of severity that was included in GINA consensus. Among the tested group, in 6 cases autoimmune aggression diseases were diagnosed: 2 patients with mild asthma, 2 moderate, and 2 severe. All patients were treated at the Healthy Lungs Clinic.

Blood for analysis of IL-25 was sampled from every patient, using the ELISA method.

Spirometry was done to all the patients (during medical examinations at the clinic). The inclusion criterion was diagnosed chronic asthma during the disease control period. Exclusion criteria were age below 18 and over 85 years, as well as loss of control over the disease. Volunteers did not suffer from any chronic 
illnesses, including allergic diseases. Laboratory tests were carried out at Świętokrzyskie Oncology Centre in the Institute of Cancer Markers. We received permission from the Bioethics Committee to carry out the tests.

\section{Results}

Among all respondents no elevated level of IL-25 was identified, whereas among 17 of the respondents higher concentrations of IL-25 were identified. Among them were 4 volunteers (20\%) and 13 patients suffering from with asthma, including 6 suffering from chronic severe asthma (30\%), 4 (20\%) - moderate, $3(15 \%)$ - mild. Among them, 3 patients had coexisting systemic disease ( 2 - severe asthma, 1 - mild asthma). A colour reaction was observed in 17 cases; however, it was not as significant as differentiation between the blind test and the lowest calibration point at the calibration curve (Tables 3 and 4).

Among volunteers who were identified with higher IL-25 levels compared to other respondents, one fact is worth considering: all the respondents had infection of the respiratory tracts just after the test. All of them had positive familial history of allergic disease. However, the respondents were free from any chronic diseases (Table 5).

Table 3. The age distribution of patients

\begin{tabular}{|lcccc|}
\hline $\begin{array}{l}\text { Number } \\
\text { of persons } \\
\text { in total }\end{array}$ & $18-29$ & $30-44$ & $45-59$ & $60-82$ \\
\cline { 2 - 5 } 80 & 12 & 23 & 24 & 21 \\
\hline
\end{tabular}

Table 4. Distribution of people with higher levels of IL-25 than other people

\begin{tabular}{|lcccc|}
\hline All together & $\begin{array}{c}\text { Volun- } \\
\text { teers }\end{array}$ & $\begin{array}{c}\text { Patients } \\
\text { with } \\
\text { chronic } \\
\text { severe } \\
\text { asthma }\end{array}$ & $\begin{array}{c}\text { Patients } \\
\text { with } \\
\text { chronic } \\
\text { moderate } \\
\text { asthma }\end{array}$ & $\begin{array}{c}\text { Patients } \\
\text { with } \\
\text { chronic } \\
\text { mild } \\
\text { asthma }\end{array}$ \\
17 & 4 & 6 & 4 & 3 \\
\hline
\end{tabular}

Table 5. Number of volunteers' family members suffering from various allergic diseases

\begin{tabular}{|ccccc|}
\hline $\begin{array}{c}\text { Volun- } \\
\text { teers }\end{array}$ & $\begin{array}{c}\text { Atopic } \\
\text { dermatitis }\end{array}$ & $\begin{array}{c}\text { Allergic } \\
\text { rhinitis }\end{array}$ & Asthma & $\begin{array}{c}\text { Other } \\
\text { allergic } \\
\text { diseases }\end{array}$ \\
1 & & 1 & 1 & \\
2 & 4 & 4 & 2 & \\
3 & & 1 & 1 & \\
4 & & 1 & 1 &
\end{tabular}

Due to the fact that all patients had controlled asthma, the spirometry results were normal - without symptoms of obstruction.

\section{Discussion}

Research which has been published to date suggests that IL-25 can activate eosinophils during allergic dermatitis [14] and is one of the key cytokines which take part in Th2 response in asthma [13, 15]. This interleukin takes part in the induction of inflammation in respiratory tracts. It is known that asthma is a chronic inflammatory disease of the respiratory tracts $[12,16]$. Especially vital is that action of the IL-25 cytokine in controlling the initiation and severity of the course of Th2 response is done via other cytokines: IL-4, IL-5, and IL-13. This leads to dominance of Th2 response. It is known that the dominance of Th2 over Th1 is characteristic of allergic diseases [13]. It facilitates the process of penetration of neutrophils through the walls of blood vessels into inflamed tissues. The neutrophils are significant factors in the development of severe asthma. The above data suggest that the concentration of interleukin should increase along with the increase of the severity of the disease. However, its mechanism of action is well known in the case of the laboratory animals, but it requires further research in the case of humans [12]. In the study no precise answer was given. However, it should be noted that despite the lack of clear results, respondents among whom higher concentration of IL-25 interleukin was identified [17] suffered from severe asthma [6] or moderate asthma [4]; among them were also volunteers [4]. However, they all had positive familial history of allergic diseases. The fact that these volunteers had some features of infections after the research is not negligible. It is possible that during the test they had subclinical inflammation. The obtained results may, to some extent, suggest that the more severe the course of asthma, the higher the concentration of IL-25; however, the results are preliminary. We truly hope that further research will help to obtain more precise data because asthma is associated with enormous socioeconomic costs [1]. The most costly treatment - multi-drug regime - concerns severe asthma, especially so-called difficult-totreat asthma [2, 17-19]. It seems that application of a single therapeutic means (e.g. antibody) not only reduce costs but also facilitates treatment of individual patients and, in some cases, enables maintaining control over the disease. This is why the IL-25 test seems to be crucial.

\section{Conclusions}

Perhaps the lack of elevated levels of IL-25 in serum in all patients was due the fact that these were people with controlled asthma. In the future patients should be checked during exacerbations of asthma and have it tried the response time to the maximum so that we can measure lower concentrations, which within a standard procedure have not been varied 
(found below the lowest standard). Therefore, we take our survey as preliminary to further understanding the action of this cytokine in patients with bronchial asthma.

\section{Conflict of interest}

The authors declare no conflict of interest.

\section{References}

1. Światowa strategia rozpoznawania, leczenia i prewencji astmy (GINA). Medycyna Praktyczna, wydanie specjalne 2007; 1: 21-7.

2. Bobrowski M, Kuna P, Pietruczuk M. The role of chemokines in asthma. J Labor Diagn 2011; 3: 323-30.

3. Desai D, Brightling C. Cytokine and anti-cytokine therapy in asthma: ready for the clinic? Clin Exp Immunol 2009; 158: 10-9.

4. Seys SF, Grabowski M, Adriaensen W, Decraene A, Dilissen E, Vanoirbeek JA, Dupont U, Ceuppens JL, Bullens IM. Sputum cytokine mapping reveals an "IL-5, IL-17A, IL-25” - high pattern associated with poorly controlled asthma. Clin Exp Allergy 2013; 43: 1009-17.

5. Gołąb J, Jakóbisiak M, Lasek W. Immunologia. Wydawnictwo Naukowe PWN, Warsaw 2002; 198-221.

6. Czarny-Dzialak M, Gluszek S. Stężenie IL-17 w surowicy $\mathrm{w}$ przebiegu ostrego zapalenia trzustki z uwzględnieniem stopnia ciężkości choroby. Prz Gastroenterol 2009; 4: 31-40.

7. Czarny-Dzialak M, Gluszek S. The role of interleukine-25 in the pathogenesis of intensines' and airways' inflammation diseases. Studia Medyczne 2010; 16: 29-31.

8. Stock P, Lombardi V, Kohlrautz V, Akbari O. Introduction of airway hyperreactivity by IL-25 is dependent on a subset of invariant NKT cells expressing IL-17RB. J Immunol 2009; 182: 5116-22.

9. Wang YH, Liu YJ. Thymic stromal lymphopoietin, OX40Iigand, and interleukin-25 in allergic responses. Clin Exp Allergy 2009; 39: 798-806.

10. Miossec P, Korn T, Kuchroo VK. Interleukin-17 and type 17 helper T cells. N Engl J Med 2009; 9: 888-98.

11. Hurst SD, Muchamuel T, Gorman DM, Gilbert JM, Clifford T, Kwan S, Menon S, Seymour B, Jackson C, Kung TT, Brieland JK, Zurawski SM, Chapman RW, Zurawski G, Coffman RL. New IL-17 family members promote Th1 or Th2 responses in the lung: in vivo function of the novel cytokine 11-25. J Immunol 2002; 169: 443-53.

12. Graczyk M, Bartuzi Z. Zapalenie eozynofilowe przewodu pokarmowego - rola komórek kwasochłonnych. Prz Gastroenterol 2007; 2: 230-4.

13. Barlow JL, McKenzie AN. IL-25: a key requirement for the regulation of type-2 immunity. Biofactors 2009; 35: 178-82.

14. Tang W, Smith SG, Beaudin S, Dua B, Howie K, Gauvreau G, O’Byrne PM. Ekspresja receptora IL-25 i IL-25 na eozynofilach u pacjentów z astmą alergiczną. Int Arch Allergy Immunol 2014; 163: 5-10.

15. Cheng D, Xue Z, Yi L, Shi H, Zhang K, Huo X, Bonser LR, Zhao J, Xu Y, Erie OJ, Zhen G. Epithelial interleukin-25 is a key mediator in Th2-high, corticosteroid-responsive asthma. Am J Respir Crit Care Med 2014; 190: 639-48.

16. Czarny-Dzialak M, Gluszek S. Czy IL-25 może stanowić wspólne ogniwo patomechanizmu łączące astmę i alergiczny nieżyt nosa? Studia Medyczne 2011; 27: 65-8.
17. Corren J, Mansfield LE, Pertseva T, Blahzko V, Kaiser K. Efficacy and safety of fluticasone/formoterol combination therapy in patients with moderate-to-severe asthma. Respir Med 2013; 107: 180-95.

18. Tan RA, Corren J. Clinical utility and development of the fluticasone/formoterol combination formulation (Fiutiform) for the treatment of asthma. Drug Des Devel Ther 2014; 8: 1555-61.

19. Radhakrishna N, Tay TR, Hore-Lacy F, Hoy R, Dabscheck E, Hew M. Profile of difficult to treat asthma patients referred for systematic assessment. Respir Med 2016; 117: 166-73.

\section{Address for correspondence:}

Małgorzata A. Czarny-Działak MD, PhD

Department of Family Medicine and Geriatrics Institute of Medical Sciences

Faculty of Medicine and Health Science

Jan Kochanowski University

ul. Malachitowa 32A, 25-705 Kielce, Poland

Phone: +48 602570179

E-mail: drmczarny@interia.pl 